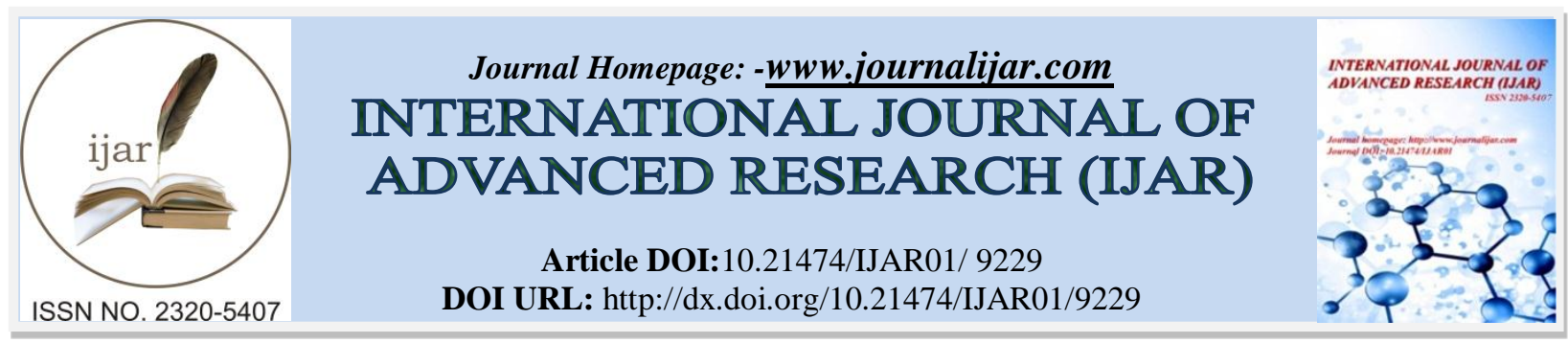

RESEARCH ARTICLE

\title{
UTILIZATION OF ETHNOMEDICAL HEALTHCARE PRACTICES IN NEPAL: A MESSAGE FOR HEALTH POLICY MAKERS.
}

Lal Mani Adhikari, Shanker Lal Menaria and Ritu Prasad Gartoulla.

PhD Scholar, Department of Sociology, Mewar University, Chittorgarh, Rajsthan, India.

\section{Manuscript Info}

Manuscript History

Received: 06 April 2019

Final Accepted: 08 May 2019

Published: June 2019

Key words:-

Ethnomedicine, healthcare, utilization, primary health care, policy, message

\begin{abstract}
Ethnomedical healthcare practices are indigenous healing and curing practices, other than conventional medicine practices that has been widely adopted approaches to seek health care in Nepal from ancient times. Though government has policy of free Primary Health Care service provided at basic administrative levels, the cost of receiving it is still putting the burden in financing the healthcare. The utilization rate of public health care found low in the study population. This could be at least partially affected by various factors such as poor coverage and poor quality of health services and inadequate resources to meet the current demand of growing population. The study revealed that the availability, affordability, accessibility and acceptability of majority of the ethnomedical healthcare service utilization was higher than the public healthcare. The barriers to improve the availability, accessibility and acceptability of primary healthcare need to be identified and the policy and strategic implementation is recommended.
\end{abstract}

Copy Right, IJAR, 2019,. All rights reserved.

\section{Introduction:-}

Ethnomedical healthcare practices (EHCP) refers to the practices of indigenous healing and curing practices based on social, cultural and belief system across different human populations (Krippner, 2005). These practices were developed from the indigenous knowledge, indigenous healing, folk medicine, faith healing or magico-religious based practices of healing relating to disease or illnesses which are the products of indigenous cultural development and are not explicitly derived from the conceptual framework of modern medicine (Rubel \& Hass, 1996). There are different ethnomedical healthcare service providers practicing the various ethnomedical practices in Nepal, identified with their various local names across different cultural context such as faith healers, religious healers, herbalists, Self-medication practices, Chinese or Tibetan practitioners, Drug Retailers, Ayurvedic practitioners (Gartoulla, 2008). EHCP are usually informal, unrecognized by the government, but yet to interact with the rest of the health system for maintaining the overall healthcare of people (Poudyal, 2011).

The Government of Nepal, Ministry of Health and Population has the policy on free Primary Health Care (PHC) service provisions to the people which is based on the modern medicine principles and practices referred as "Basic Health Care Services (BHCS)" through the service outlets called "Health Post" throughout the country.

Though the PHC has been found universally the major strategy among the most national health policies in developing countries to improve the general health status of population. Specifically, PHC has been designed to 
provide the basic and essential modern health care facilities for all segments and strata of the population. However, due to scarce resources the utilization rate is considerably low among rural population (Subedi, 1992). The government owned Department of Health Service reports that the number of primary health care service delivery outlets in Nepal includes, 3,808 Health Posts (HP), 200 PHC Centers 123 public hospitals, and 1,715 non-public health facilities. Further, the service has been provided through 12,180 primary health care outreach clinic, including a total of 16,022 Expanded Programme of Immunization clinics provided immunization services which were supported by 49,001 female community health volunteers (FCHV) at community level outreach . In the same way, the ayurvedic service which is also a accreditated system by ministry, has provided PHC services through two Ayurveda hospitals, 14 zonal Ayurveda dispensaries, 61 district Ayurveda health centres and 305 Ayurveda dispensaries towards Ayurveda health services (Department of Health Service, 2017).

Majority of the population is Nepal is rural nearly covering $83 \%$ who are living in rural areas and they are not being able to get quality PHC service. A performance of health posts and PHC Centers delivering services in the rural areas is far from satisfactory so this leads to seeking either ethnomedical practitioners or private health providers for their health service needs. Accessibility of modern medication in the rural communities in Nepal is very low even increasing no of service outlets including seasonal mobile camps are being provided by government. Government of Nepal has attempted service deliveries through extensive outlets for periphery people. But there are many questions arising about quality, access of service and acceptance of services. Merely establishment of health institutions, training of health workers cannot ensure health service without assessment of their socioeconomic status, cultural and behavioral diagnosis (Subba, 2001).

The study of utilization of EHCP was based on independent variables such as sociodemographic status, illness characteristics, socio-economic status, Social institution variables, patients' individual culture, preference and practices. These variables influence the health seeking behavior of the patients towards ethnomedical approaches and consequently the utilization of EHCP to seek improve their health status.

The major aim of this study is to extrapolate the utilization of ethnomedical healthcare practices from the perspectives of different dimensions of utilization namely Affordability, Availability, Accessibility and Acceptability symbolized as 4 A's" of Ethnomedical as well as biomedical service providers and featuring these results into the improvement of PHC services in the current context.

\section{Methods:-}

\section{Study setting:}

The study was conducted at the natural settings. The districts randomly selected were Solukhumbu, Dhankuta and Morang from Mountain, Hills and the Terai respectively covering all three geographical regions of Eastern Nepal. The districts were selected based on the sociocultural parameters such as proportion of ethnic population, multiculturalism and the development indicators of each.

\section{Study Design:}

Descriptive cross-sectional Survey research design was adopted as the research methodology for this study. Multistage sampling design was used to select the clusters and wards of the selected districts followed by the systematic sampling to select the households for the survey. A total of 385 respondents were interviewed with using semi-structured questionnaire tool. The study was conducted as the part of partial fulfillment of the requirement of the degree "Doctor of Philosophy" entitled "A study of Ethnomedical Health Care Approaches Towards Primary Health Care in Nepal".

\section{Study participants:}

Study participants were household heads both male and female with age above 18 years.

\section{Study Procedure:}

Ethical approval for this study was received from Nepal Health Research Council prior to the data collection. A household survey was conducted between January 2016 to January 2017 in selected Village Development Committees and Municipalities of selected districts visiting by researcher himself. The study used pre-piloted semistructured questionnaire tool in Nepali language to capture the information on Availability, Affordability, Accessibility and Acceptability of ethnomedical healthcare practices along with biomedical healthcare practices 
utilized. The utilization data were based on the information provided by the participant for his or her family members during the course of health seeking process or treatment. The raw data were entered on Statistical Package for Social Sciences (SPSS) version 17.0 developed by International Business Machines (IBM) Corporation, USA. The data once entered verified with the filled questionnaires to avoid the mistyping. The data was analyzed then to plot the findings and reporting.

\section{Results:-}

A) Sociodemographic Profile

There were $52.5 \%, 40.3 \%$ and $7.3 \%$ respondents from the Terai, Hills and Mountain region respectively, $79.7 \%$ rural and $20.3 \%$ urban by residence; $67 \%$ male and $33 \%$ female by gender and by ethnicity viz. 21.8\% Madhesi, $16.9 \%$ of Chhetri, 13.2\% Brahmin, 6.2\% Dalit, 2.6\% Newar, 1.0\% from Muslim and other ethnicities 38.2\% accordingly. The participants age ranges from 18 years to 95 years with the mean age of 39.7 years (Table: 1).

\section{B) Utilization of EHCP based on 4 "A's" factors}

The overall study found that Faith healing was relatively more frequently utilized practices compared with biomedical practices. Faith Healing was found most affordable and accessible followed by Drug Retailers practices. Drug retailers service was the most acceptable and available followed by Faith Healers. Among Biomedical providers, private service utilization is the most acceptable, available and accessible in comparison to public healthcare service utilization. Public biomedical health service was the most affordable in comparison to the private biomedical service.

Comparing the utilization of EHCP among the total participants, it was found that the Faith Healing and Drug Retailers service were the most utilized EHCP (> 80\%) among rural while the Drug retailers service were the most sought EHCP (>94\%) followed by Faith healers (>62\%) among urban participants. Similarly, utilization of service from Religious Healers, Ayurvedic practitioners and Herbalist were found more frequently utilized among the urban participants than rural participants.

\section{C) Service Utilization of Faith Healers among ever visiting participants}

The study found that the utilization of Faith healers services was significant among ever visited rural participants when compared with urban counterparts (chi square test <0.002) but not significant for biomedical health care providers (chi square test $<0.426$ ) (table 3).

\section{D) Participants monthly income and effectiveness of utilization of EHCP}

The study revealed that Drug Retailers service was very helpful for two-third (67\%) participants followed by almost half (44\%) for faith healers and almost one-third (31\%) participants towards for Religious Healers services for the effectiveness of utilization of EHCP among all practices. From the income category, the Faith healing was more utilized among the low-income category and gradullay declining it's effectiveness among the increasing income category participants. In contrast, the Drug Retailers service effectiveness was found to be gradually increased when the income category increases (table 4).

The mean expenditure per visit for utilizing service with faith healers was 184.32 Nepalese Rupees (NPR) which was the lowest among all EHCP. In the similar way, NPR 304 for Herbalist, NPR 319 for Ayurveda, NPR 364 for Religious Healers and NPR 457 for Drug Retailers. However, the cost of utilization per visit for biomedical providers was found comparatively very high with NPR 991 for Public and NPR 4639 for private biomedical healthcare service. Although the basic healthcare service is free, the cost of expenditure per visit has been spent on travel, accommodation and diagnostic and treatment cost which are charged by referred hospitals. This shows that the public healthcare service couldnot covered all the health service needs of people either in quality, coverage or the dimension. The paired sample T-test on total expenditure for EHCP utilization per visit comparing with biomedical service utilization was significant $(\mathrm{p}<0.000)($ table 5$)$.

\section{Discussions:-}

The study revealed that the EHCP was more available, accessible, acceptable and affordable health care practices adopted by people. According to the World Health Organization report on the healthcare utilization, EHCP known as, by the different names, widely adopted practice worldwide for curing illness. Mostly faith healing, traditional medicine, Complementary and Alternative medicine (CAM), ritual healing and religious practices among the 
different cultural ethnicities. The report says that, $70 \%-95 \%$ of population relies on traditional medicines for primary care in developing countries of Asia, Africa, Latin America and the Middle East, $70 \%$ to $90 \%$ of their populations in Canada and $42 \%$ in USA have used traditional medicines under the name of CAM. However, the report also emphasizes on its integration into national health policies (Robinson \& Zhang, 2011). In India and in many other countries, Ayuveda, Unani, Siddha and Homoeopathy (AYUSH) known as the Indian system of medicine is established which is preferred method of health care for many chronic and old aged disorders and this might play a vital role in fighting with contemporary health problems (Bureau, 2012). Gartoulla and Phuyal mentioned that more than $80 \%$ of the Nepalese adopted the herbal medicines that may be served from Ayurvedic practitioners or Herbalist in Nepal (Gartoulla, 2008) and (Phuyal, 2006).However, this study revealed that the utilization of herbal medicine, but not Ayurveda, has been declining due to the policy implications of free healthcare policy mandated by government.

The voice of resurgence of ethnomedical healthcare service has also been prioritized by many researchers. In india, a study suggests that the native ethnomedical practices for improving mother and child's health where the public healthcare system is dominant has still strong utilization (Pushpangadan \& George, 2010). However, the policy for the integration of traditional medicine in national health systems is still in dillema due to lack of studies on its impact such as efficacy, safety, quality, standardization, regulation (Agostinho, 2011).

\section{Conclusion:-}

The study emphasizes the improvement on supply side of public health service delivery, which is more accessible, available, acceptable to all people now which is covered by ethnomedical service and explore approaches and measures to replace it for achieving more resilient healthcare system. The study could derive some features on barriers on availability, accessibility and acceptability of modern public healthcare that compelled to seek utilization of ethnomedical healthcare practices specially in rural areas of Nepal. Current ethnomedical healthcare policy implications, its regulation and validation are important to protect health form its adverse effects, delay in diagnosis, care and treatment during the health care seeking process. A further study needs to be conducted to identify the barriers of utilization for modern healthcare practice which is crucial to improve the coverage, quality and effectiveness of services and tackle them through developing realistic policies and its due implementation in line with direction of universal health coverage approaches. The study of utilization of ethnomedical health care practices had captured the health seeking behavior and utilization practices of people comparing with biomedical healthcare so enabling policy makers and health planners to identify the different dimensions and aspects to improve the overall public health care service delivery in terms of its availability, accessibility and acceptability of service utilization.

\section{Acknowledgement:-}

The author acknowledges to the support made by participants of this study. LMA declares that the study is conducted as a partial fulfillment of corresponding author's $\mathrm{PhD}$ study and the fund is solely contributed by corresponding author. LMA drafted the paper based on the data analysis, revision of this and SLM and RPG contributed in the overall guidance to shape up the paper and contributed in finalizing the paper.

Table 1:-Sociodemographic profile of participants

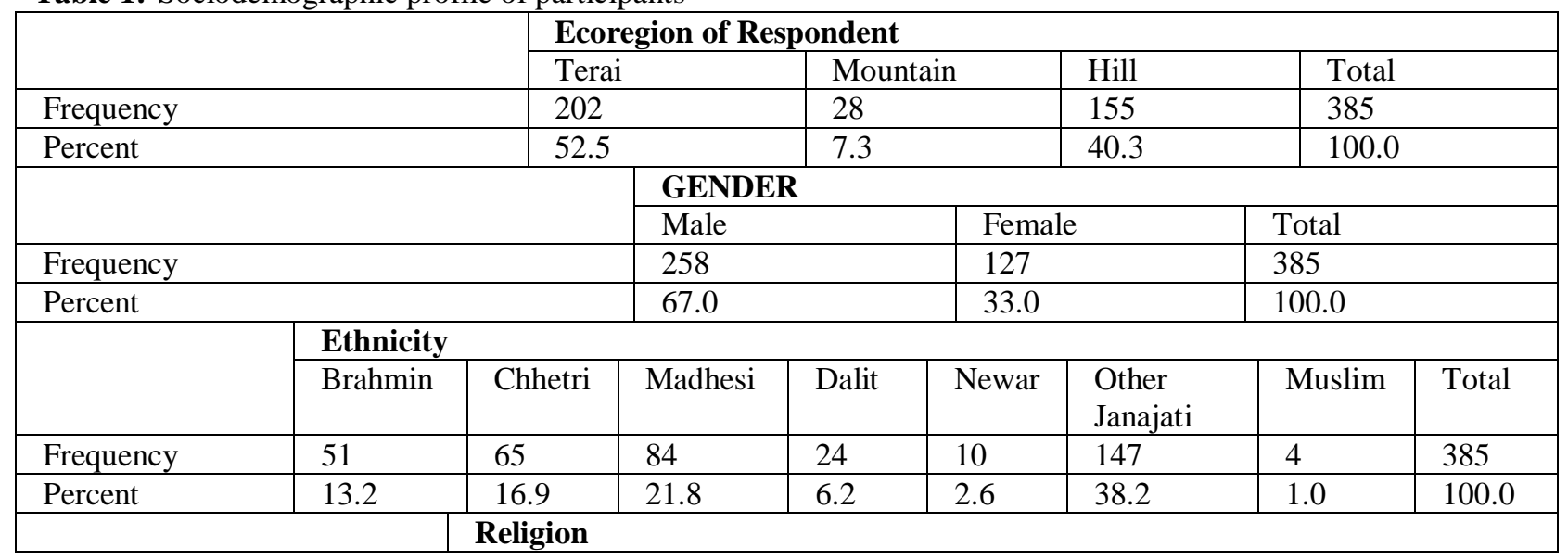




\begin{tabular}{|l|l|l|l|l|l|}
\hline & Hindu & Buddhism & Muslim & Kirat & Total \\
\hline Frequency & 342 & 24 & 3 & 16 & 385 \\
\hline Percent & 88.8 & 6.2 & .8 & 4.2 & 100.0 \\
\hline \multirow{2}{*}{} & Family Type & \multicolumn{4}{|l|}{} \\
\cline { 2 - 6 } & Nuclear & Single Parent & Joint/Extended & Total \\
\hline Frequency & 280 & 44 & 61 & 385 \\
\hline Percent & 72.7 & 11.4 & 15.8 & 100.0 \\
\hline
\end{tabular}

Table 2:-Responses on 4 A's form the perspectives of utilization of different health care services

\begin{tabular}{|c|c|c|c|c|c|c|c|c|c|c|}
\hline \multirow{2}{*}{$\begin{array}{l}\text { Type of } \\
\text { Providers }\end{array}$} & \multicolumn{3}{|c|}{ Affordability } & \multicolumn{2}{|c|}{ Acceptability } & \multicolumn{2}{|c|}{ Availability } & \multicolumn{2}{|c|}{ Accessibility } & \multirow[t]{2}{*}{ Total } \\
\hline & & Very & Somewhat & Very & Somewhat & Very & Somewhat & Very & Somewhat & \\
\hline \multirow{2}{*}{$\begin{array}{l}\text { Faith } \\
\text { Healers }\end{array}$} & $\mathrm{F}$ & 271 & 27 & 204 & 83 & 215 & 82 & 237 & 59 & 385 \\
\hline & $\%$ & 70.4 & 7 & 53 & 21.6 & 55.8 & 21.3 & 61.6 & 15.3 & 100 \\
\hline \multirow{2}{*}{$\begin{array}{l}\text { Religious } \\
\text { Healers }\end{array}$} & $\mathrm{F}$ & 174 & 10 & 143 & 35 & 151 & 31 & 158 & 24 & 385 \\
\hline & $\%$ & 45.2 & 2.6 & 37.1 & 9.1 & 39.2 & 8.1 & 41 & 6.2 & 100 \\
\hline \multirow{2}{*}{ Herbalist } & $\mathrm{F}$ & 83 & 7 & 61 & 28 & 30 & 19 & 40 & 10 & 385 \\
\hline & $\%$ & 21.6 & 1.8 & 15.8 & 7.3 & 7.8 & 4.9 & 10.4 & 2.6 & 100 \\
\hline \multirow{2}{*}{$\begin{array}{l}\text { Drug } \\
\text { Retailers }\end{array}$} & $\mathrm{F}$ & 255 & 68 & 255 & 64 & 226 & 83 & 243 & 68 & 385 \\
\hline & $\%$ & 66.2 & 17.7 & 66.2 & 16.6 & 58.7 & 21.6 & 63.1 & 17.7 & 100 \\
\hline \multirow{2}{*}{ Ayurveda } & $\mathrm{F}$ & 74 & 26 & 79 & 22 & 35 & 36 & 41 & 25 & 385 \\
\hline & $\%$ & 19.2 & 6.8 & 20.5 & 5.7 & 9.1 & 9.4 & 10.6 & 6.5 & 100 \\
\hline \multirow{2}{*}{ Homeopathy } & $\mathrm{F}$ & 8 & 1 & 5 & 5 & 1 & 1 & 1 & 3 & 385 \\
\hline & $\%$ & 2.1 & 0.3 & 1.3 & 1.3 & 0.3 & 0.3 & 0.3 & 0.8 & 100 \\
\hline \multirow[t]{2}{*}{ Chinese } & $\mathrm{F}$ & 1 & & 2 & & 1 & 2 & 1 & 1 & 385 \\
\hline & $\%$ & 0.3 & & 0.5 & & 0.3 & 0.5 & 0.3 & 0.3 & 100 \\
\hline \multirow{2}{*}{$\begin{array}{l}\text { Private } \\
\text { Biomedical }\end{array}$} & $\mathrm{F}$ & 145 & 119 & 319 & 36 & 150 & 119 & 187 & 103 & 385 \\
\hline & $\%$ & 37.7 & 30.9 & 82.9 & 9.4 & 39 & 30.9 & 48.6 & 26.8 & 100 \\
\hline \multirow{2}{*}{$\begin{array}{l}\text { Public } \\
\text { Biomedical }\end{array}$} & $\mathrm{F}$ & 251 & 89 & 257 & 81 & 220 & 108 & 232 & 98 & 385 \\
\hline & $\%$ & 65.2 & 23.1 & 66.8 & 21 & 57.1 & 28.1 & 60.3 & 25.5 & 100 \\
\hline
\end{tabular}

Source: Field Survey, 2017

Table 3:-Ever visiting faith healers among urban and rural participants

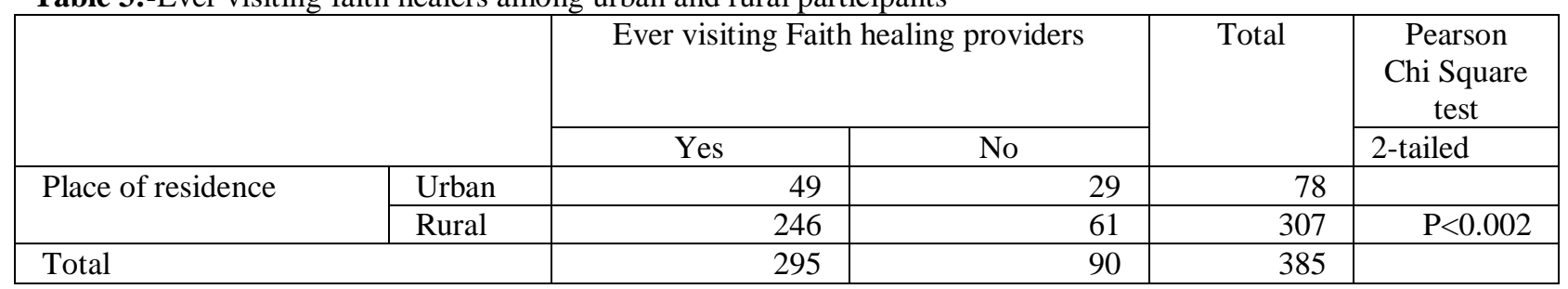

Source: Study Survey, 2017

Table 4:-Monthly Income of participants and effectiveness of EHCP

\begin{tabular}{|c|c|c|c|c|c|c|c|c|}
\hline \multirow[t]{2}{*}{ Type of EHCP } & \multirow{2}{*}{$\begin{array}{l}\text { Effectiveness } \\
\text { level }\end{array}$} & \multicolumn{6}{|c|}{ Total monthly income of respondents in Nepalese Rupees } & \multirow[t]{2}{*}{ Total } \\
\hline & & $\begin{array}{l}\text { Up to } \\
10000\end{array}$ & $\begin{array}{l}10001 \\
\text { to } \\
20000\end{array}$ & $\begin{array}{l}20001 \\
\text { to } \\
30000\end{array}$ & $\begin{array}{l}30001 \\
\text { to } \\
40000\end{array}$ & $\begin{array}{l}40001 \\
\text { to } \\
50000\end{array}$ & $\begin{array}{l}50001 \\
\text { to } \\
60000\end{array}$ & \\
\hline Faith Healers & Very helpful & $67 \%$ & $53 \%$ & $39 \%$ & $46 \%$ & $36 \%$ & $30 \%$ & $44 \%$ \\
\hline Religious Healers & Very helpful & $33 \%$ & $35 \%$ & $31 \%$ & $20 \%$ & $40 \%$ & $35 \%$ & $31 \%$ \\
\hline Herbalist & Very helpful & $17 \%$ & $7 \%$ & $16 \%$ & $10 \%$ & $13 \%$ & $15 \%$ & $12 \%$ \\
\hline Drug retailers & Very helpful & $42 \%$ & $75 \%$ & $64 \%$ & $65 \%$ & $72 \%$ & $65 \%$ & $67 \%$ \\
\hline Ayurveda & Very helpful & $8 \%$ & $16 \%$ & $22 \%$ & $22 \%$ & $28 \%$ & $35 \%$ & $22 \%$ \\
\hline Homeopathy & Very helpful & & $3 \%$ & $3 \%$ & $1 \%$ & $4 \%$ & & $2 \%$ \\
\hline Chinese/Tibetan & Very helpful & & $1 \%$ & & & & & $0 \%$ \\
\hline Clinical Practitioners & Very helpful & $100 \%$ & $92 \%$ & $90 \%$ & $90 \%$ & $89 \%$ & $95 \%$ & $91 \%$ \\
\hline
\end{tabular}




\begin{tabular}{|l|l|l|l|l|l|l|l|l|}
\hline Self-Help practices & Very helpful & $8 \%$ & $13 \%$ & $18 \%$ & $17 \%$ & $11 \%$ & $20 \%$ & $16 \%$ \\
\hline
\end{tabular}
Source: Field Survey, 2017

Table 5:-Health Expenditure per visit for utilization of EHCP-paired sample T-test

\begin{tabular}{|c|c|c|c|c|c|c|c|c|c|}
\hline \multicolumn{10}{|c|}{ Paired Samples Test } \\
\hline & & \multicolumn{5}{|c|}{ Paired Differences } & \multirow[t]{5}{*}{$\mathrm{t}$} & \multirow[t]{5}{*}{ df } & \multirow{5}{*}{$\begin{array}{l}\text { Sig. } \\
\text { (2- } \\
\text { taile } \\
\text { d) }\end{array}$} \\
\hline & & \multirow[t]{4}{*}{ Mean } & \multirow{4}{*}{$\begin{array}{l}\text { Std. } \\
\text { Deviatio } \\
\mathrm{n}\end{array}$} & \multirow{4}{*}{$\begin{array}{l}\text { Std. } \\
\text { Error } \\
\text { Mean }\end{array}$} & \multirow{3}{*}{\multicolumn{2}{|c|}{$\begin{array}{l}95 \% \\
\text { Interval of } \\
\text { Difference }\end{array}$}} & & & \\
\hline & & & & & & & & & \\
\hline & & & & & & & & & \\
\hline & & & & & Lower & Upper & & & \\
\hline $\mathrm{Pa}$ & Total_Expenses_ & - & 6456.73 & 329.06 & - & & - & 38 & .000 \\
\hline ir & Ethno & 4044.28 & 496 & 568 & 4691.27 & 3397.28 & 12.2 & 4 & \\
\hline 1 & $\begin{array}{l}\text { Total_Expenses_ } \\
\text { Bio }\end{array}$ & 052 & & & 662 & 442 & 90 & & \\
\hline
\end{tabular}

Source: Field Survey, 2017

\section{References:-}

1. Agostinho, A. B. (2011, July). INTEGRATION OF TRADITIONAL MEDICINE IN HEALTH SYSTEM IN AFRICA. Universitas Forum, 2(2), 1-2.

2. Bureau. ( 2012, November 9). India sets up information cells in many countries to promote AYUSH. New Delhi, India: pharmabiz.com accessed on 21 Nov 2012.

3. CBS. (2012). National Population and Housing Census 2011 (National Report). Kathamandu: Central Bureau of Statistics, Government of Nepal,National Planning Commission Secretariat.

4. Department of Health Service. (2017). Annual report 2016/2017. Kathmandu: Ministry of Health and Population.

5. Gartoulla, R. P. (2008). Textbook of Medical Sociology and Medical Anthropology. Kathmandu, Nepal: Reasearch center for Integrated Development (RECID).

6. Krippner, S. (2005, October 8). THE IMPACT OF ALLOPATHIC BIOMEDICINE ON TRADITIONAL HEALING SYSTEMS. Retrieved November 23, 2012, from World Congress of Ethnomedicine, Munich, Germany: http://stanleykrippner.com/papers/munich.htm

7. Phuyal, N. (2006). Indigenous people of Nepal and their healing practices. Education and development,(22, Special Issue), 70-71.

8. Poudyal, A. (2011). Role of Indigenous Healers in PHC. Health Prospect, (10), 68.

9. Pushpangadan, P., \& George, V. (2010, January ). Ethnomedical practices of rural and tribal populations of India with special reference to the mother and childcare. Indian Journal Of Traditional Knowledge, 9(1).

10. Robinson, M. M., \& Zhang, X. (2011). THE WORLD MEDICINES SITUATION 2011. Geneva: World Health Organization.

11. Rubel, A. J., \& Hass, M. R. (1996). Ethnomedicine. In R. edition (Ed.), Handbook of Medical Anthropology: Contemporary Theory and Methods (p. 116). Westport, CT: Greenwood Press.

12. Subba, N. R. (2001). Health Seeking Behavior of Rajbanshi Community in Baijanathpur and Katahari of Morang

Nepal. http://www.nhrc.org.np/ojs/index.php?journal=nhrc\&page=article\&op=viewFile\&path\%5B\%5D=57\&path\%5B $\% 5 \mathrm{D}=100$ accessed on 9 May 2011, 1-8. Kathamndu: Journal of Nepal Health Research Council.

13. Subedi, J. (1992). Medical Pluralism exemplified in Nepal: A proposal for maximizing the Health care benefit. Sociological Focus, 25(4), 321. 